ACTA THERIOLOGICA

Vcl. 26, 16: 275--283, 1981

\title{
Demographic Processes in an Urban Population of the Striped Field Mouse
}

\author{
Joanna BABIŃSKA-WERKA, Joanna GLIWICZ \& Jacek GOSZCZYŃSKI
}

\begin{abstract}
Babińska-Werka J., Gliwicz J. \& Goszczyński J., 1981: Demographic processes in an urban population of the striped field mouse. Acta theriol., 26, 16: 275-283 [With 2 Tables \& 1 Fig.]

Studies on an urban population of Apodemus agrarius (Pallas, 1771) were carried out in one of old cemeteries in Warsaw. Average density of these rodents was 54 individuals/ha. It was found that the cause of such high density of field mice in a city was, in addition to the absence of competitive species, the considerable isolation of the study population, making it difficult for individuals to migrate. The limited reproduction characteristic of isolated populations was observed. The natality index (per female) and survival up to the trappable period were very low, while at the same time mortality among the older, independent individuals of the urban population was smaller than in a suburban population.
\end{abstract}

[Dept. of Wildlife Management, Warsaw Agricultural University, Rakowiecka 26/30, 02-528 Warszawa]

\section{INTRODUCTION}

During long-term studies on urban populations of Apodemus agrarius (Pallas, 1771), several specific characteristics of these populations were observed which distinguished them from populations of the same species living under more natural conditions. The initial comparative studies suggested that urban populations differ from those living on the periphery of towns or in suburban areas in respect of reproduction, mortality, age structure (Andrzejewski et al., 1978) and density (Goszczyński, 1979a). Two possible sources of these differences were indicated: (1) the absence of competitive species, which usually co-occur with the field mouse in habitats outside towns (Andrzejewski et al., 1978) and (2) the specific nature of the habitats occupied by this species in a town (their patchy distribution within the city area and the composition of their biocenoses, and particularly phytocenoses, Babińska-Werka et al., 1979). This latter characteristic undoubtedly affects the diet of A. agrarius in town (Babińska-Werka, 1981).

The purpose of the present study is to trace variations in numbers, natality and mortality in one of the urban populations during the period of the reproductive season, to compare them with those of a suburban population and to discuss the causes of the differences stated between the populations. The data used for comparison were obtained by Gliwicz 
(1981) from control and experimental populations inhabiting a suburban tree stand Młociny Wood. In the experimental plot, 1 ha in size, only individuals of $A$. agrarius were allowed to remain while in the control plot of the same size a whole natural community of rodents composed of three species was left unchanged. Comparison of the results obtained from the urban population with the results of the experiment made it possible to estimate to what extent the demographic processes of the urban population are affected by the absence of competitors, and to what extent they are determined by other characteristics of an urban habitat.

\section{STUDY AREA, MATERIAL AND METHODS}

The study area was situated in the old Orthodox Cemetery in Warsaw. The cemetery is isolated from other green areas in the city by compact built-up areas, busy streets and additionally by the cemetery wall. The vegetation in the cemetery is similar in structure and species composition to the Tilio-Carpinetum association. The trapping area was situated in the oldest part of the cemetery, rarely visited by humans.

Live-traps were placed over an area of 1 ha in a grid of $15 \times 15 \mathrm{~m}$. Two traps baited with oats were placed on each of 48 trap station. Trapping programme was carried out four times in 1978: in April (18-22), June (21-30), August $(22-31)$ and October (11-18). The traps were inspected every 24 hours.

The CMR method was employed. The captured animals were weighed, sexed and marked with individual numbers by toe-clipping. In the case of females notes were taken about their puberty and reproductive condition. Additionally for all mature females vaginal smears were taken in order to estimate the proportion of pregnant females in the population, using the method described by Bujalska (1970).

During the course of four trapping programmes a total of 143 individuals of A. agrarius were caught. Total number of captures was 399 , the average individual being caught 2.7 times in the traps. In addition to field mice single individuals of the house mouse Mus musculus (Linnaeus, 1758) and of the common vole Microtus arvalis (Pallas, 1779) were also caught.

\section{VARIATIONS IN NUMBERS}

The density of the population during the study period (June-October) was high and subject to little variation (50-69 individuals/ha). There was a small peak in numbers during the second half of August (Fig. 1). It proved impossible to estimate population density in April because of very poor trappability during the first trapping period. As in 1978 reproduction began relatively late, it was possible to distinguish in June, with a considerable degree of accuracy, young individuals (born approxi- 
mately from the second half of May onwards) from adult, overwintered individuals. The numbers of the overwintered individuals present in the population at the beginning of reproductive season was calculated on the basis of the numbers of these individuals in June and of the mortality index $(\mu=0.007)$, taken from the suburban populations (in which this was very similar on both experimental and control plots). It was estimated that 32 individuals were present in the po-

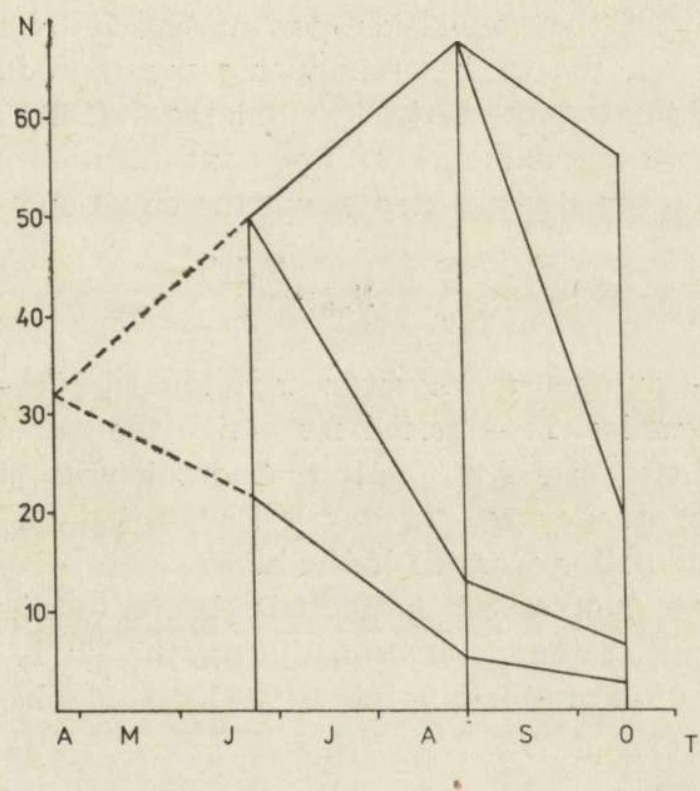

Fig. 1. Variations in numbers of an urban population of Apodemus agrarius. Numbers for April were calculated (see text for explanation).

pulation at the beginning of May. This figure is of course burdened with some degree of error and is only an approximate value.

Average density of individuals on 1 hectare area during the study period was estimated to be 54 individuals. This result fully accords with the results of an earlier density estimation made twice during summer and autumn 1977 for the whole 5-hectare area of a southern part of the cemetery by Petersen's method, when the values of 88 and 39 individuals per 1 ha were obtained (Goszczyński, 1979a).

In Młociny Wood the mean density of 19 individuals on 1 hectare area was obtained for the control population, and 32 individuals for the experimental population. The results of the experiment show quite clearly that the removal of competitors leads to an increase in numbers of A. agrarius (Gliwicz, 1981). The density of the urban population, 
however, is far greater than this of the experimental population. In order to determine whether the higher density of the urban population was due to its greater reproduction or reduced mortality (in relation to the suburban population) an analysis of these two processes was made.

\section{NATALITY AND SURVIVAL OF YOUNG}

The natality of the population was measured by the number of individuals born in the study area during the reproductive season. This value was estimated by Bujalska's method (1967, 1970), based on a knowledge of the numbers of pregnant females present in the population during the study period, using the equation:

$$
N_{n b}=\frac{N_{p} T L}{t_{p}}
$$

where $N_{n b}$ - number of newborn individuals, $N_{p}$ - average number of pregnant females, $T$ - period for which the calculations were made, $L-$ mean litter size $\left(=6\right.$, after Andrzejewski et al., 1978), $t_{p}$ duration of pregnancy ( $=22$ days). The estimated number of young born in the population was 451 individuals.

The ratio of number of individuals born to the number of all females present in the population during the study period was taken as the index of reproduction intensity, its value being 6.3 young per female.

Table 1

Comparison of reproduction and survival of offspring in urban and suburban populations.

\begin{tabular}{|c|c|c|}
\hline Population & $\begin{array}{c}\text { Number of newborn } \\
\text { per female }\end{array}$ & $\begin{array}{l}\text { Survival of sucklings } \\
\text { up to the trappable } \\
\text { age (in } \% \text { ) }\end{array}$ \\
\hline $\begin{array}{l}\text { Urban } \\
\text { Suburban: control } \\
\text { experimental }\end{array}$ & $\begin{array}{l}6.3 \\
7.7 \\
5.9\end{array}$ & $\begin{array}{l}27 \\
26 \\
35\end{array}$ \\
\hline
\end{tabular}

An analogical index was calculated for the suburban experimental and control populations and, as can be seen from comparison of these values (Table 1), intensity of reproduction in the urban population is similar to the reproduction in the experimental population, and is lower than in the control population. This means that in the urban population some factors inhibiting the reproduction are in action. One of such factors, namely lower rate of sexual maturation of females in 
urban population than in a suburban ones, was found in our earlier study (Andrzejewski et al., 1978).

Out of 451 individuals born in the population only $120\left(27^{\%} \%\right)$ survived up to the "trappable" age (on an average to the age of 6 weeks) (Table 1). This is a relatively low value when compared with survival of the offspring from the suburban experimental population, and is close to the survival of the control population. One must remember that the experimental population was, like the urban population, free of competitors.

To sum up it may be stated that both natality and survival of young were on a relatively low level in the urban population.

\section{MORTALITY AMONG THE TRAPPABLE PART OF THE POPULATION}

The rate of disappearance from the population of independent (trappable individuals was estimated for two periods: June-August and August-October. Since the length of these periods differed, the rate of mortality (or disappearance) $\mu$, was calculated per day according to the formula:

$$
N_{t}=N_{0} e^{-\mu t}
$$

where $N_{0}$ - numbers at the beginning of period $t, N_{t}$ - numbers at the end of period $t, t$ - length of period in days.

Table 2

Comparison of mortality rates $(\mu)$ for trappable individuals of urban and suburban populations.

( $\mu$ calculated according to formula: $N_{+}=N_{0} e^{-\mu t}$ where $t=1$ day)

\begin{tabular}{lccc}
\hline \multicolumn{1}{c}{ Period } & Urban population & \multicolumn{2}{c}{ Suburban } \\
\cline { 3 - 4 } & & control & experimental \\
\hline June-July & & 0.055 & 0.030 \\
June-August & 0.021 & 0.045 & 0.015 \\
July-September & 0.025 & 0.042 & 0.040 \\
August-October & 0.023 & 0.047 & 0.028 \\
September-October & & & \\
Mean mortality & &
\end{tabular}

The figure obtained for the first period (summer) was $\mu=0.021$ per day, and $\mu=0.025$ for the second period (autumn). It may therefore be taken that the disappearance of individuals in the period June-October took place evenly in this population. It is difficult to compare it with the mortality of individuals in the suburban population, since there disappearance rates were estimated for slightly different periods of time (Table 2). It may, however, be stated that in general mortality 
(or disappearance) in the urban population was considerably lower than in the control (natural) suburban population, and slightly lower (particularly during the summer period) than that of the experimental population. Analogical results for winter period indicating the low mortality of individuals in urban populations in comparison with suburban populations were obtained in earlier studies (Andrzejewski et al., 1978).

\section{SEX RATIO}

Sex ratio measured by the percentage of males in the population was $48 \%$ in June, $52 \%$ in August and $52 \%$ in October. Sex ratio did not therefore differ from $1: 1$ and remained unaltered over the whole reproductive season.

This result is somewhat astonishing, since it was found from data for two years, obtained earlier from an urban population in Łazienki Park (Andrzejewski et al., 1978), that there was a statistically significant excess of males during the whole reproductive season. As no significant differences in sex ratio were found in comparable material collected during the same period from the city outskirts and suburban populations, it was considered that sex structure differing from the ratio $1: 1$ is a specific feature of urban populations. In the light of the results presented here the previous conclusion seems to be premature. The phenomenon of the significant excess of males in urban populations must be considered as only local or periodical in character.

\section{DISCUSSION AND CONCLUSIONS}

The value of the data presented above, and of conclusions based on them is strongly limited, as they refer to only one urban population of $A$. agrarius and to only one year of study. It must, however, be emphasized that the area taken for the studies is fairly characteristic of a city environment. The majority of the results obtained here (apart from sex structure) confirm the general trends which were implied by earlier (1975-1976) somewhat fragmentary data collected from three populations situated within an urbanization gradient: urban, peripheral and suburban. It is therefore to be expected that the general picture obtained here is also representative for other urban populations of A. agrarius and, perhaps, for other non-synanthropic rodents inhabiting urban areas.

One of the basic characteristics of the population under study was 
high density, not encountered in populations living under more natural conditions, as reported earlier by Goszczyński (1979a). The phenomenon of high density is partly connected with the absence in urban areas of species which in other habitats compete with the field mouse (Andrzejewski et al., 1978; Gliwicz, 1981). As, however, the density is 1.5 times greater than the density of the suburban population experimentally deprived of competitors, there must be some further factors stimulating high population numbers under urban conditions. One of these factors may be the different composition of food consumed by rodents in a city (Babińska-Werka, 1981), which leads also to quicker individual growth rate (Liro, personal communication; Sikorski, personal communication) and greater body weight (Andrzejewski et al., 1978) in urban populations. The second reason for high rodent density may be the lower predator penetration on urban green areas (Goszczyński, $1979 b)$. Finally the third cause may be the "insular" character of urban populations. The effect of increased density in confined populations, in which free emigration of the excess individuals is held back by impassable barriers, is well known in literature dealing with small mammals (Petrusewicz, 1963, 1978; Krebs et al., 1969; Łomnicki, 1978; Gliwicz, 1980). On the basis of a general knowledge of the distribution in Warsaw of green areas occupied by field mice (Babińska-Werka et al., 1979) it may be stated that many of the urban populations live on "islands" formed by patches of suitable habitats. Among such confined populations is the population described in this paper.

There was stated (Gliwicz, 1980) that in typical rodent confined populations the regulation of numbers is achieved by lowered reproduction of individuals and high mortality of their offspring. Loses of independent individuals in such populations are usually low, since their emigration and the mortality resulting from it is excluded.

The relative values of mortality, survival of youngest and of independent individuals in the population under study are similar to those found in confined populations. Natality index (per female) is far lower than in the natural (control) suburban population, but similar to that found in the experimental population, in which numbers, as the result of improved conditions, rose abruptly and then, phenomena limiting natality occured (Gliwicz, 1981). The index of survival for the youngest individuals in the urban population points to relatively great reduction of sucklings. Finally mortality among the independent individuals in the urban population is lower than in the suburban population, probably due, to the higher residence of these individuals.

To sum up, the hypothesis may be put forward that the density of non-synanthropic rodents in an urbanized habitat will usually be - in 
green areas suitable for rodents - locally higher than in more natural habitats. Reduction in the degree of isolation of green areas within a city should lead to decrease in density of locally crowded populations.

\section{REFERENCES}

1. Andrzejewski R., Babińska-Werka J., Gliwicz J. \& Goszczyński J., 1978: Synurbization processes in population of Apodemus agrarius. I. Characteristics of populations in an urbanization gradient. Acta theriol., 23: $341-358$.

2. Babińska-Werka J., Gliwicz J. \& Goszczyński J., 1979: Synurbization processes in population of Apodemus agrarius. II. Habitats of the striped field mouse in town. Acta theriol., 24: 405-415.

3. Babińska-Werka J., 1981: Food of the striped field mouse in different types of urban green areas. Acta theriol., 26: 285-299.

4. Bujalska G., 1967: Estimation of reproduction in Clethrionomys glareolus (Schreber, 1780). Small Mammal Newslett., 3: 27-28.

5. Bujalska G., 1970: Reproduction stabilizing elements in an island population of Clethrionomys glareolus (Schreber, 1780). Acta theriol., 15: 381-412.

6. Gliwicz J., 1980: Island populations of rodents: their organization and functioning. Biol. Rev., 55: 109-138.

7. Gliwicz J., 1981: Competitive interactions within a forest rodent community in Central Poland. Oikos 37.

8. Goszczyński J., 1979a: Density estimation for an urban population of the field mouse. Acta theriol., 24: 417-419.

9. Goszczyński J., 1979b: Penetration of mammals over urban green spaces in Warsaw. Acta theriol., 24: 419-423.

10. Krebs C. J., Keller B. L. \& Tamarin R. H., 1969: Microtus population biology: Demographic changes in fluctuating population of $M$. ochrogaster and $M$. pennsylvanicus in southern Indiana. Ecology, 50: 587-607.

11. Łomnicki A., 1978: Individual differences between animals and the natural regulation of their numbers. J. Anim. Ecol., 47: 461-475.

12. Petrusewicz K., 1963: General remarks on the productivity of confined populations. Ekol. pol. A, 11: 617-624.

13. Petrusewicz K., 1978: Osobnik, populacja, gatunek. Państw. Wyd. Nauk.: 1-384. Warszawa.

Accepted, February 10, 1981.

\section{Joanna BABIN̂SKA-WERKA, Joanna GLIWICZ i Jacek GOSZCZYÑSKI}

\section{PROCESY DEMOGRAFICZNE W MIEJSKIEJ POPULACJI MYSZY POLNEJ}

\section{Streszezenie}

Badaniami objęto populację myszy polnej Apodemus agrarius (Pallas, 1771) zamieszkującą teren Cmentarza Prawosławnego w Warszawie. Połowy gryzoni prowadzono w 1978 roku w okresie sezonu rozrodczego (kwiecień - październik), stosując metodę CMR. Ogółem złowiono 143 osobniki w trakcie 4 serii połowów. Do 
porównania procesów demograficznych w miejskiej populacji myszy polnej posłużyły dane uzyskane z populacji zamieszkującej podmiejski las Młociny (Gliwicz, 1981). Populację tę podano eksperymentowi polegającemu na pozostawieniu na jednohektarowej powierzchni tylko osobników Apodemus agrarius, a na powierzchni kontrolnej całego zespołu gryzoni.

Srednie zagęszczenie myszy polnej na Cmentarzu Prawosławnym było wysokie i wynosiło 54 osobniki/ha (Ryc. 1). Było to zagęszczenie 1,5-krotnie wyższe niż w populacji podmiejskiej na Młocinach eksperymentalnie pozbawionej konkurentów. Stwierdzono, że przyczyną tak wysokiego zagęszczenia myszy polnej w mieście oprócz braku gatunków konkurujących może być wysoki stopień izolacji badanej populacji, utrudniający migrację osobników. Potwierdzeniem tego jest podobieństwo wskaźnika rozrodu, przeżywalność młodych i samodzielnych osobników na Cmentarzu Prawosławnym i w populacjach izolowanych. Wskaźnik rozrodczości (na 1 samicę) i przeżywalność do okresu lownego w populacji na Cmentarzu Prawosławnym kształtują się na stosunkowo niskim poziomie (Tabela 1). Jednocześnie śmiertelność samodzielnych osobników populacji miejskiej jest mniejsza niż w populacji podmiejskiej (Tabela 2).

Wysunięto hipotezę, że zagęszczenie gryzoni niesynantropijnych w środowisku zurbanizowanym będzie lokalnie - na terenach zielonych przydatnych dla gryzoni - $\mathrm{z}$ reguły wyższe niż $w$ środowiskach niezurbanizowanych i to tym wyższe im dany teren jest bardziej izolowany od innych. Zmniejszenie stopnia izolacji poszczególnych terenów zielonych miasta powinno prowadzić do utrzymania się liczebności tych gryzoni na nieco niższym poziomie. 